\title{
The Effect of Local Government Characteristics and BPK Audit Opinions on the Financial Performance of Local Governments (Study on Local Governments in South Sumatra)
}

\author{
Indra Satriawan ${ }^{1, *}$ Ardiyan Natoen ${ }^{1}$ Periansya ${ }^{1}$ Sopiyan $\mathrm{AR}^{1}$ \\ ${ }^{1}$ Department of Accounting, Sriwijaya State Polytechnic \\ *Corresponding author. Email: indra72@polsri.ac.id
}

\begin{abstract}
This research aims to determine the effect of local government characteristics and the Supreme Audit Agency (BPK) audit opinions on the financial performance of the local governments studies at the Local Government in South Sumatra. Regional characteristics in this research use the Level of Regional Wealth (TKA) and the financial performance of local governments is measured by the Regional Financial Independence Ratio (RKKD). The research objects consisted of eighteen district, city and provincial governments in South Sumatra from 2016 to 2019. This research used secondary data using population data and processed using SPSS. The results showed that regional characteristics had a positive and significant effect on the financial performance of local governments, while BPK's opinion had a positive but insignificant effect on the performance of local governments in South Sumatra.
\end{abstract}

Keywords: local government, BPK audit opinion and local government financial performance.

\section{INTRODUCTION}

\subsection{Background}

In managing and regulating their own government affairs, the local government is given the obligation to submit accountability for the implementation of the Regional Budget (APBD) in the form of financial reports that have been audited by the Supreme Audit Agency (BPK). The Governor/ Regent/ Mayor submits a draft regional regulation concerning the accountability for the implementation of the Regional Budget (APBD) to the Regional People's Representative Council (DPRD) in the form of a financial report that has been audited by the Supreme Audit Agency (BPK), no later than 6 (six) months after the fiscal year ends.

On the other hand, nowadays the demands are increasingly being directed to the accountability that must be given by state administrators for the trust entrusted to them. In other words, the performance of government agencies, especially their financial performance, is getting more attention now, because people are starting to question the benefits they get from government agency services. There is a greater demand from society for transparency and public accountability by public sector institutions (Masdiantini and Erawati, 2016). This has resulted in local governments being obliged to carry out regional financial management effectively and efficiently. So that this condition encourages the increasing need for measuring financial performance of state administrators who have received the mandate from the people. This requires performance measurement, which is an important component that can provide feedback on plans that have been implemented and to assess the accountability of local government financial performance in producing public services. Regional financial performance as a benchmark in determining financial policies and good government financial governance.

Government Regulation Number 12 of 2019 concerning Regional Financial Management states that "performance is the output/ result of activities/ programs that will be or have been achieved in connection with the use of budget with measurable quantity and quality". Meanwhile, financial performance is a measure of performance that uses financial indicators. Because it uses financial indicators, the right analytical tool to 
measure financial performance is financial analysis (Hidayat and Ghozali, 2013).

The problem of decreasing the performance of the Local Government in South Sumatra in 2019 which is seen from the amount of Regional Incentive Fund Revenue (DID) and the high level of regional financial dependence on the central government based on Balancing Fund receipts as well as differences in the results of previous research, make the author is interested in researching and reviewing these factors on the government's financial performance. In addition, the authors are interested in Article 1 of Law Number 15 of 2006 concerning the Supreme Audit Agency which states that the Supreme Audit Agency (BPK) is the only state institution that has the duty and authority to conduct audits of the management and responsibility of State finances. In connection with this, it is necessary to examine whether the BPK Audit Opinion and Regional Original Revenue (PAD) are able to influence and improve government financial performance which is the goal of implementing regional autonomy.

From the description above, the researcher took the title of research on the effect of Local Government characteristics and BPK Audit Opinions on Local Government Financial Performance (Study on Local Government in South Sumatra).

\subsection{Formulation of the problem}

Based on the above background, the problem in this research is whether the characteristics of the Local Government and BPK Audit Opinions on the Financial Performance of the Local Government (Study on Local Government in South Sumatra).

\section{LITERATURE REVIEW HYPOTHESIS DEVELOPMENT}

AND

Since 1976 there has been a theory called Agency Theory. In agency theory, two conflicting economic actors are explained, namely the principal and the agent. This theory is the main theory used in this research because it is able to explain the relationship between the Audit Opinion of the Supreme Audit Agency (BPK) on the financial performance of the Local Government of South Sumatra Province, in short, this theory is able to explain governance.

Based on agency theory, it describes the relationship between the community and the government, where the relationship arises because of a contract established by the community (as the principal) for the government (as an agent) that provides services for the benefit of the community. The community will supervise the objectives of the government. In carrying out this supervision, the community requires the government to be accountable for the management of resources entrusted to the government through financial reports.

\subsection{Regional Original Revenue (PAD)}

Based on Law Number 33 of 2004 concerning Financial Balance between Central and Local Government, Article 1 point 18, Regional Original Revenue is revenue obtained by regions and collected based on regional regulations in accordance with statutory regulations. According to Halim (2007: 96), Regional Original Revenue is revenue obtained by a region from sources within its own territory which is collected based on the applicable legislation. Original Regional Revenue as a source of regional revenue that needs to be increased in order to be able to bear part of the expenditures needed for government administration and development activities which increase every year so that a wide, real and responsible regional autonomy can be implemented (Darise, 2008: 25).

\subsection{Regional Wealth Level (TKD)}

In previous research, Mustikarini and Fitriasasi (2012) used PAD compared to total income as a proxy for measuring the level of regional wealth. According to Law no. 33 of 2004, Regional Original Revenue is revenue obtained by a region from sources within its own region which is collected based on regional regulations in accordance with the prevailing laws and regulations. So in this research the variable level of wealth is measured by the formula:

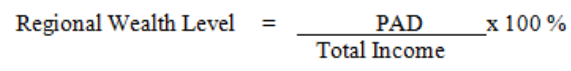

\subsection{Local Government Financial Performance}

Financial performance is the result or achievement that has been achieved by company management in managing company assets effectively during a certain period. Financial performance is needed by companies to determine and evaluate the level of success of the company based on the financial activities that have been carried out (Rudianto: 2013: 189). Furthermore, measurement or performance measurement is defined as a financial and non-financial indicator of a job performed or the results achieved from an activity, a process or an organizational unit. Performance measurement is a form of accountability, where a higher assessment is a guide that must be met, performance measurement data can be a further program improvement.

Indicators to measure local government efforts to improve performance can use several ways to measure Regional Financial Performance, one of which is by using the Regional Financial Performance Ratio. Some of the ratios that can be used are: PAD Effectiveness Ratio, Regional Financial Efficiency Ratio, Conformity Ratio, Growth Ratio, and Regional Financial Independence Ratio. In this research, indicators to measure the regional financial performance of 
researchers use the Regional Financial Independence Ratio (RKKD).

Regional Financial Independence Ratio (RKKD) shows the level of ability of a region to self-finance government activities, development and services to people who have paid taxes and levies as a source of revenue needed by the region. The ratio of regional financial independence is indicated by the amount of regional original revenue compared to regional revenue from other sources (transfer income), including: tax sharing, non-tax revenue sharing for natural resources, general allocation funds and special allocations, emergency funds and loans (Abdul Halim 2007: L-5). The formula used to calculate the Independence Ratio is:

$$
\text { RKKD }=\frac{\text { PAD }}{\text { Transfer Income }} \times 100 \%
$$

The Ratio of Regional Financial Independence describes the dependence of regions on Transfer Income (external data sources). The higher the Regional Financial Independence Ratio means that the level of regional dependence on external assistance is lower and vice versa. The Ratio of Regional Financial Independence also describes the level of community participation in regional development. The higher the Regional Financial Independence Ratio, the higher the community's participation in paying local taxes and levies, which are the main components of Regional Original Revenue. The higher the people pay local taxes and levies, it shows that the level of community welfare is getting higher. As a guide in seeing the pattern of relationships with regional capabilities (from the financial side) the table can be presented as follows:

Table 1. Relationship Patterns and Regional Capability Levels

\begin{tabular}{|c|c|c|}
\hline $\begin{array}{l}\text { Financial } \\
\text { Capability }\end{array}$ & $\begin{array}{l}\text { Independence } \\
(\boldsymbol{\%})\end{array}$ & $\begin{array}{l}\text { Relationship } \\
\text { Pattern }\end{array}$ \\
\hline Very low & $0 \%-25 \%$ & Instructive \\
\hline Low & $25 \%-50 \%$ & Consultative \\
\hline Moderate & $50 \%-75 \%$ & Participative \\
\hline High & $\begin{array}{c}75 \% \\
100 \%\end{array}$ & Delegative \\
\hline
\end{tabular}

Source: Reksohadiprojo and Thoha in Hermi Oppier (2013:82)

\subsection{Previous Research}

Endri Parwanto, Puji Harto (2017) The effect of BPK Examination Results on Local Government Financial Performance The results show that the audit opinion and the timeliness of submitting local government financial reports have a significant positive effect, while the audit findings and audit follow-up have no significant effect on the government's financial performance. area.

I Gusti Made Ary Anggara Tama (2018) The Effect of Regional Head Characteristics, Government Size, and Audit Findings on Regional Financial Performance. The results in this research indicate that audit findings have a significant negative effect on regional financial performance. Government size is not proven to be a factor determining financial performance in local government, and the characteristics of regional heads, only the tenure factor (variable) has a positive and significant effect on the financial performance.

Puja Rizqy Ramadhan (2018) The effect of Local Government Characteristics and BPK Audit Findings on Regency/ City Government Financial Performance. This research shows that the characteristics of local governments (size of the region, level of regional wealth, regional spending) and BPK audit findings (audit findings on SPI \& audit findings on noncompliance with statutory provisions) have a simultaneous effect on the financial performance of district / municipal governments in North Sumatra.

Based on the description above, the framework in this research can be described as follows:

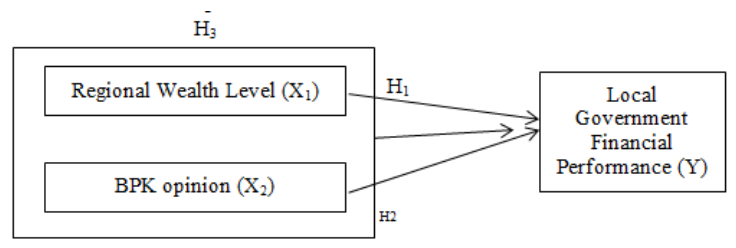

Figure 1. Framework

\subsection{Hypothesis Development}

From the framework above, the following hypothesis is compiled:

\subsubsection{The Effect of the Regional Wealth Level on the Local Government Financial Performance Score}

The amount and increase in Regional Original Revenue (PAD) contributions will greatly play a role in the independence of local governments or the performance of local governments (Florida, 2007 in Nugroho and Rohman, 2012). Sumarjo (2010) also explains that an increase in Regional Original Revenue (PAD) is a supporting factor of macroeconomic performance. Positive growth encourages investment so that investment will simultaneously stimulate improvements in regional infrastructure. Good regional infrastructure and high investment in an area will increase PAD. Adi (2006) in Sumarjo (2010) states that the increase in PAD should be supported by the increase in the public services quality. The good public services quality will reflect the good performance of the local government. 
The description above is supported by the results of research by Wenny (2012) and research by Mustikarini and Fitriasasi (2012) which found that local government revenue has a positive effect on local government performance. Julitawati, et al (2012) also found that PAD affects the financial performance of district / city governments. Therefore, the hypothesis in this research is as follows:

Hypothesis 1: The level of regional wealth has a positive effect on the Local Government financial performance score.

\subsubsection{Effect of BPK Audit Opinion on Local Government Financial Performance Scores}

BPK opinion is an opinion of the examination on financial statements of the Local Government. The better the opinion given by the BPK illustrates the better the financial performance of the Local Government. Thus, the final hypothesis of this research is:

Hypothesis 2: BPK opinion has a positive effect on the financial performance of local governments,

\subsubsection{The Influence of the regional wealth level and BPK Audit Opinion on the Financial Performance of Local Government}

The regional wealth level and the dependence level of the central government and BPK Audit opinion will support each other and have a positive effect on the financial performance of Local Governments. The better this variable illustrates the better the financial performance of the Local Government. Thus, the final hypothesis of this research is:

Hypothesis 3: The regional wealth level and the Audit Opinion of BPK have a positive effect on the financial performance of local governments.

\section{RESEARCH METHODOLOGY}

\subsection{Population and Sample}

The method used for sample selection in this research is saturated sampling. Saturated sampling is a sampling technique when all members of the population are used as samples. Saturated sample is also called a census, where all members of the population are sampled. Hence, in this research, the samples are 18 (eighteen) district / city and provincial governments in the South Sumatra region.

\subsection{Research variable}

\subsubsection{Dependent Variable}

\subsubsection{Local Government Financial Performance}

Local Government financial performance is proxied by the Regional Financial Independence Ratio (RKKD) which shows the level of a region's ability to selffinance government activities, development and services to people who have paid taxes and levies as a source of revenue needed by the region. The ratio of regional financial independence is indicated by the amount of regional original revenue compared to regional revenue from other sources (transfer revenue), including: tax sharing, non-tax revenue sharing for natural resources, general allocation funds and special allocations, emergency funds and loans (Abdul Halim 2007: L-5).

\subsubsection{Independent Variable}

The independent variables in this research are the regional wealth level, the dependence level on ventral government, and BPK Audit opinion.

\subsection{Regional Wealth Level Variable}

In previous research, Mustikarini and Fitriasasi (2012) used PAD compared to total revenue as a proxy for measuring the regional wealth level. According to Law no. 33 of 2004, Regional Original revenue is the revenue obtained by a region from sources within its own region which is collected based on regional regulations in accordance with the prevailing law and regulation. Regional Original revenue consists of local taxes, regional levies, the results of separated regional wealth management, and other legal regional revenue (Ardhani, 2011). Positive growth will stimulate investment, which will also boost improvements in regional infrastructure. It is expected that the improvement of regional infrastructure will improve the quality of public services.

\subsection{BPK Audit Opinion}

According to Masdiantini and Erawati (2016), basically, audit opinion both in the private sector and in the public sector is divided into four categories which are measured using an ordinal scale sorted from worst opinion to best opinion, namely (1) Not Expressing Opinion (TMP), (2) Not Fair (TW), (3) Fair with Exception (WDP), (4) Fair without Exception with Explanatory Paragraphs (WTP-DPP) and (5) Fair without Exception (WTP). However, in this research, the measurement for audit opinion is grouped into two categories, i.e.WTP is given 2 scores and not WTP is given one score (Dummy variable

\section{RESEARCH RESULTS AND DISCUSSION}

\subsection{Research result}

\subsubsection{Descriptive statistics}

Based on the results of the test with SPSS, the descriptive statistics for the research data were obtained as shown in the table. 2 below: 
Table 2. Descriptive Statistics Results

\section{Descriptive Statistics}

\begin{tabular}{|c|l|l|l|l|l|}
\hline & $\mathrm{N}$ & Minimum & Maximum & Mean & Std. Deviation \\
\hline Regional Wealth Level & 72 &, 03 &, 39 &, 1003 &, 08748 \\
BPK opinion & 72 & 1,00 & 2,00 & 1,9722 &, 16549 \\
$\begin{array}{c}\text { Local Government } \\
\text { Financial Performance }\end{array}$ & 72 &, 03 &, 75 &, 1328 &, 15200 \\
Valid N (listwise) & 72 & & & & \\
\hline
\end{tabular}

Based on table 2, from all district, city, and provincial governments in the South Sumatra region that were sampled, counted for a period of 4 years and made the results of the objects in this research as much as $(\mathrm{N})$ 72. The results of descriptive test obtained $\mathrm{N}$ value or the total test for each sample, the minimum value of each sample tested, the maximum value of each sample tested, the mean, and the standard deviation for each independent or dependent sample of each sample tested.

From the table above, the independent variables, namely Regional Wealth Tk and Local Government Performance, the minimum value (lowest) is 0.03 and the maximum (highest) value is 2 from the BPK Opinion variable.

\subsubsection{Data Normality Test Results}

Based on the test results with SPSS, the normality test results for the research data were obtained as shown in the table. 3 below:

Table 3. Normality Test Results

One-Sample Kolmogorov-Smirnov Test

\begin{tabular}{|ll|r|}
\hline & & \multicolumn{2}{|c|}{$\begin{array}{c}\text { Unstandardized } \\
\text { Residual }\end{array}$} \\
\hline $\mathrm{N}$ & Mean & 72 \\
Normal Parameters & $\mathrm{a}$, b & Std. \\
& Deviation &, 02521177 \\
& Absolute &, 115 \\
Most Extreme Differences & Positive &, 115 \\
& Negative &,- 081 \\
Kolmogorov-Smirnov Z & &, 979 \\
Asymp. Sig. (2-tailed) & &, 293 \\
\hline
\end{tabular}

a. Test distribution is Normal.

b. Calculated from data.
Table 3 states that the results of the normality test using the One-Sample Kolmogorov-Smirnov are presented in the table above, the Asymp value. Sig. (2tailed) from the output above is 0.293 , it can be concluded statistically that the independent and dependent variables in this research have normally distributed data because they have a significance value above 0.05 so that this research can be continued.

\subsection{Multiple Linear Regression Analysis}

Multiple linear regression analysis is used to determine statistically the relationship between the independent variables and the dependent variable. The regression model used in this research is as follows:

$$
\mathrm{Y}=\mathrm{a}+\mathrm{bX} 1+\mathrm{bX} 2+\mathrm{e}
$$

The results of data test with multiple regression in the research shown in the table below:

$$
\mathrm{Y}=-0,13+1,713 \mathrm{X} 1-0,003 \mathrm{X} 2
$$

\subsection{Determination Coefficient Test R2}

The determination coefficient reflects the magnitude of the influence of changes in the independent variables in carrying out changes in the dependent variable, with the aim of measuring the truth and goodness of the relationship between the variables in the model used.

To determine the effect of the influence of Local Government Characteristics (level of regional wealth, level of dependence on the central government) and BPK Audit Opinion on Local Government Financial Performance (Study on Local Government in South Sumatra), the results of the calculations shown in the following table. 
Table 4. Results of the Determination Coefficient of $\mathrm{R}^{2}$

\begin{tabular}{|l|r|r|r|r|}
\hline $\begin{array}{l}\text { Mode } \\
1\end{array}$ & R & R Square & $\begin{array}{c}\text { Adjusted R } \\
\text { Square }\end{array}$ & $\begin{array}{c}\text { Std. Error of } \\
\text { the Estimate }\end{array}$ \\
\hline 1 &, $986^{\mathrm{a}}$ &, 972 &, 971 &, 02576 \\
\hline
\end{tabular}

a. Predictors: (Constant), Opini BPK, Ketergantungan

Daerah, Kekayaan Daerah

b. Dependent Variable: Kinerja Pemda

Source: Data processed by SPSS

\section{5. $t$ Statistical Test}

To find out and test the relationship or influence of each independent variables on the Characteristics of Local Government and the Audit Opinion of the BPK on Local Government Financial Performance (Study on Local Government in South Sumatra). The estimation results from the model are as follows

Table 6. Partial Test Results (t Test)

\begin{tabular}{|c|c|c|c|c|c|c|}
\hline \multirow{2}{*}{\multicolumn{2}{|c|}{ Model }} & \multicolumn{2}{|c|}{ Unstandardized Coefficients } & \multirow{2}{*}{$\begin{array}{c}\begin{array}{c}\text { Standardized } \\
\text { Coefficients }\end{array} \\
\text { Beta }\end{array}$} & \multirow[t]{2}{*}{$\mathrm{t}$} & \multirow[t]{2}{*}{ Sig. } \\
\hline & & B & Std. Error & & & \\
\hline \multirow{3}{*}{1} & (Constant) &,- 032 &, 037 & &,- 870 & ,387 \\
\hline & Kekayaan Daerah & 1,713 & ,036 & ,986 & 48,207 & ,000 \\
\hline & Opini BPK &,- 003 & 019 &,- 004 &,- 184 &, 855 \\
\hline
\end{tabular}

Based on the results of the analysis presented in table 4, it is known that the determination coefficient for the regression model or Adjusted R Square between the Characteristics of Local Government (level of regional wealth, level of dependence on the central government) and BPK Audit Opinion on the financial performance of local governments is $0.971 \%$. This value means that $97.1 \%$ of local government financial performance is influenced by the Characteristics of the Local Government and the Audit Opinion of the BPK. Meanwhile, $2.9 \%$ of local government financial performance is influenced by other variables that are not included.

\subsection{F Statistical Test}

This test is used to determine the effect of all independent variables on the dependent variable. The results of the Simultaneous Significance Test (Test F) are shown in the table below:

Table 5. The results of the Simultaneous Significance Test (Test F)

\section{ANOVA $^{\mathrm{a}}$}

\begin{tabular}{|c|c|c|c|c|c|}
\hline Model & $\begin{array}{l}\text { Sum of } \\
\text { Squares }\end{array}$ & df & $\begin{array}{c}\text { Mean } \\
\text { Square }\end{array}$ & $\mathrm{F}$ & Sig. \\
\hline Regression & 1,594 & 2 & ,797 & $\begin{array}{r}1172, \\
328\end{array}$ &, $000^{\mathrm{b}}$ \\
\hline Residual &, 047 & 69 & ,001 & & \\
\hline Total & 1,640 & 71 & & & \\
\hline
\end{tabular}

a. Dependent Variable: Kinerja Pemda

b. Predictors: (Constant), Opini BPK, Kekayaan Daerah Source: Data processed by SPSS

Based on the table above, the significance level of $0.000<0.005$ indicates that the variables of Local Government Characteristics (regional wealth level) and BPK Audit Opinion simultaneously have a significant effect on the financial performance of local governments. Thus, H3 is accepted.
Based on the table above:

1. The variable level of regional wealth has an effect on the financial performance of local governments. From the table above, the sig value is $0.000<0.05$. Statistically, this variable affects the financial performance variable, so the level of regional wealth has a significant positive effect on the financial performance variable of local government. So it can be concluded that $\mathrm{H} 1$ is accepted.

2. BPK opinion variables affect the financial performance of local governments. From the table above, the sig value is $0.855>0.05$. Statistically this variable has an effect on the financial performance variable, so the level of regional wealth has no significant effect on the variable of local government financial performance. So it can be concluded that $\mathrm{H} 2$ is rejected.

\subsection{Discussion}

\subsubsection{The Influence of Regional Wealth Level on Local Government Financial Performance}

Based on the analysis results, the regional wealth level variable has a significant effect on the financial performance of local governments. It is shown by the significance level of 0.000 which is less than 0.05 . Based on the results of the regression test, it was found that the higher the level of regional wealth, there would be an increase of $1 \%$, so there could be an increase in local government financial performance.

The level of regional wealth can be seen from the size of the PAD proxies owned by the local government. PAD is one of the sources of funding used by local governments in financing regional development which has implications for the services provided to the community (Sumarjo, 2010). In addition, PAD is the backbone of regional financing for providing services to the community. Local government with a large size and 
large PAD should have a high performance score. If it turns out to have a low score, then it must evaluate its performance and understand that it has worse performance than the local government with the smaller size and less PAD. Local governments with large size and $\mathrm{PAD}$ are required to better manage and to better utilize the wealth they have for the sake of serving the community. The results in this research support the research of Mustikarini and Fitriasasi (2012) which concluded that the level of regional wealth as measured by PAD value on total local government revenue has a significant positive effect on the performance score of district / city governments. Sumarjo's research (2010) concludes that intergovermental revenue measured by the amount of PAD has a positive effect on local government financial performance. In addition, Julitawati, et al (2012) concluded that PAD and balancing funds simultaneously and partially affect the financial performance of district / city governments in Aceh province. This research does not support the research of Wenny (2012) which concludes that PAD does not affect local government financial performance.

\subsubsection{The Influence of BPK's opinion on Local Government Financial Performance}

Based on the analysis results, the BPK opinion variable has no significant effect on the financial performance of local governments. It is shown by the significance level of 0.855 which is greater than 0.05 . Based on the regression test results, it was found that if there was an increase or a better BPK opinion, there would be a decrease in the financial performance of the local government.

The results of this research are related to the BPK audit findings showing that the greater the number of BPK audit findings in a local government, the lower the performance score of the Local Government. This means that the Local Government must be more careful in matters of state financial management because this is not only related to accounting problems but also to compliance with existing regulations. The results in this research support the research of Mustikarini and Fitriasasi (2012) which concludes that the BPK audit findings have a significant negative effect on the performance scores of district / city and provincial governments.

\section{CONCLUSION}

Based on the results of the research, the conclusions obtained are:

1. The local government characteristics variables, namely the level of regional wealth, have a significant effect on the financial performance of the Local Government, while the BPK opinion has no significant effect on the financial performance of the Local Government.
2. Regional Wealth Level variable and BPK opinion variable have a significant effect on the financial performance of local governments.

3. Based on the determination test, it is known that the value of the determination coefficient for the regression model or Adjusted R Square between the Characteristics of Local Government (level of regional wealth, level of dependence on the central government) and BPK Audit Opinion on the financial performance of local governments is $0.971 \%$. This value means that $97.1 \%$ of local government financial performance is influenced by the Characteristics of the Local Government and the Audit Opinion of the BPK. Meanwhile, 2.9\% of local government financial performance is influenced by other variables that are not included.

\section{REFERENCES}

[1] Afrian, Galang. 2016. "The Influence of Regional Government Characteristics, BPK Audit Findings, and Leverage on Regional Government Financial Performance" .Jon.Jon FEKON Vol.3.No.1

[2] Agoes, Sukrisno. 2013. Auditing Practical Guidelines for Accountant Examination by Public Accountants. Edition 4. Book 1. Jakarta: Salemba Empat.

[3] Anthonius, Rante et al. 2018. "The Effect of Audit Opinions on Local Government performance with Realization of Regional Revenue and Expenditure as Intervening Variables" Journal of Regional Accounting \& Finance Volume 13, Number 2, November 2018: 123-134.

[4] Artha, Diri Risma., Prayitno Basuki \& Alamsyah Mt. 2015. "The Influence of Local Government Characteristics and Bpk Audit Findings on the Performance of Local Government Administration (Empirical Study of District / City Governments in Ntb Province)". Infestation Journal. Vol. 11. No. 2 h: 214 - 229.

[5] Supreme Audit Agency, BPK Audit Opinion, www. bpk.go.id. Retrieved 15 October 2019.

[6] Darise, N. 2008. Regional Financial Accounting, Jakarta: PT Index.

[7] Gamayuni, R., R. 2015. The Effect Of Intangible Asset, Financial Performance And Financial Policies On The Firm Value. International Journal Of Scientific and Technology Research, 4 (1): 202212.

[8] Ghozali, Imam. 2011. Application of Multivariate Analysis with the Seventh Edition of the SPSS program. Semarang: Diponogoro University Publishing Agency. 
[9] Gamayuni and Rika. 2015. "Public Sector Accounting". Bandar Lampung: AURA

[10] Halim, A. 2007. Regional Financial Management. 2007. Yogyakarta: UPP STIM YKPN.

[11] Hendriyani, Ririn, Tahar, Afrizal. 2015. "Analysis of Factors Affecting the Level of Financial Report Disclosure of the Provincial Government of Indonesia". Journal of Business \& Economics (JBE). Vol. 22. Number 1. Pp. 25-33.ISSN: 1412312625 .

[12] Hidayat, F. M. and Ghozali, M. 2013. Analysis of the Influence of Regional Financial Performance on Capital Expenditure Allocation (Studies on Districts and Cities in East Java). Scientific Journal, Malang: Brawiajaya University.

[13] Indrarti and Okky. 2011. "The Relationship between Audit Opinions on Regional Financial Reports, Regional Original Revenue (PAD) and General Allocation Funds (DAU) on Regional Financial Performance". Journal. Riau University.

[14] Jensen, M. C and W.H Meckling, 1976. "Theory of The Firm: Managerial Behavior, Agency Cost and Ownership Structure". Journal of Financial Economics, Vol 3, pp 305-360.

[15] Juliawati, et al. (2012). "The Effect of Local Own Revenue and Balancing Funds on the Financial Performance of District / City Government in Aceh Province". Thesis. Syiah Kuala University: BandaAceh.

[16] Juweny and Siti. 2016. "The Influence of Regional Government Characteristics and Audit Findings of BPK on Regional Government Performance". University of Lampung Thesis.

[17] Kusumawardani and Media. 2012. The Influence of Size, Prosperity, Legislative Size, Leverage on Financial Performance of Local Governments in Indonesia, Accounting Analysis Journal, 1 (1).

[18] Kusumawardani, Media. 2012. The Influence of Size, Prosperity, Legislative Size,

[19] Leverage on Regional Government Financial Performance in Indonesia. AccountingAnalysis Journal, Vol. 1.ISSN: 2252-6765

[20] Pass and Marfiana. 2012. "The Influence of Regional Government Characteristics and Audit Results of BPK Audit on Financial Performance of District / City Government". Faculty of Economics, Sebelas Maret University.

[21] Maiyora, Gita. 2015. "The Influence of the Characteristics of Local Government on the
Financial Performance of Local Governments". Journal. Jom FEKON vol.2. No.2

[22] Mardiasmo. 2011. "Revised Edition Taxation". Yogyakarta: Andi.

[23] Masdiantini, Erawati. 2016. The Influence of Size of Local Government, Prosperity, Intergovernmental Revenue, Bpk Audit Findings and Opinions on Financial Performance. E-Journal of Accounting at Udayana University. 14.2. ISSN: 2302-8556.

[24] Masdiantini, P. R. and Erawati. 2016. The Influence of Size of Local Government, Prosperity, Intergovernmental Revenue, BPK Audit Findings and Opinions on Financial Performance. E-Journal of Accounting, Udayana University, 14: 11501182.

[25] Meilina, ZuliaD, .Hapsari, Dini W ,. Dillak, Vayaj. 2016. "The Influence of Regional Government Characteristics and BPK Examination Results on Local Government Performance". Journal of Telkom University.

[26] Mustikarini, Widyadan Fitriasari, Debby. 2012. "The Influence of Regional Government Characteristics and Audit Findings of the BPK on the Performance of District / City Governments in Indonesia". Journal. Publisher: University of Indonesia.

[27] Noviyanti, Nur Ade \& Kiswanto. 2016. "The Effect of Local Government Characteristics, Bpk Audit Findings on Regional Government Financial Performance". Accounting Analysis Journal, Department of Accounting, Faculty of Economics, Semarang State University. ISSN 2252-6765.Vol. 5, No. 1.

[28] Pungki Ardani, (2011). The Influence of Economic Growth, Local Own Revenue, General Allocation Funds and Special Allocation Funds on the Allocation of the Capital Expenditure Budget. EJournal of Diponogoro University Semarang.

[29] Parwanto, Harto. (2017). "The Effect of BPK Examination Results on Regional Government Financial Performance" .Jurnal.Universitas Diponogoro: Central Java

[30] P. R. Ramadhan. 2018. "The Effect of Regional Government Characteristics and Audit Findings of the Supreme Audit Agency on District / City Financial Performance". Journal of Accounting \& Finance Studies, Vol. 2, No. 3, pp: 103-114.

[31] Republic of Indonesia, Law Number 15 Year 2004 concerning Audit on Management and Responsibility of Negarah Finance. 
[32] Republic of Indonesia, Law Number 32 Year 2004. about Regional Government.

[33] Republic of Indonesia, Law. Number 33 Year 2004 regarding Financial Balance between Central and Regional Government.

[34] Republic of Indonesia, Law. Number 15 Year 2006 regarding the Supreme Audit Agency.

[35] Republic of Indonesia, Law Number 59, Year 2007. concerning Amendments to the Regulation of the Minister of Home Affairs Number 13 of 2006 concerning Guidelines for Regional Financial Management

[36] Republic of Indonesia, Law. Number 23. Year 2014. concerning Regional Government.

[37] Republic of Indonesia. Law Number 9 of 2015 concerning Second Amendment to Law Number 23 of 2014 concerning Regional Government

[38] Republic of Indonesia. Government Regulation Number 12 of 2019 concerning Regional Financial Management

[39] Official, 2011. Taxation: Theory and Cases. Jakarta: Four Salemba.

[40] Retnowati, Reny. 2016. Analysis of the Influence of Regional Wealth Level, Regional Expenditure, Government Size, Leverage, and Intergovermental Revenue on Regional Government Financial Performance. E-Journal of the Muhammadiyah University of Surakarta.

[41] Rudianto.2013. Management Accounting Information for Strategic Decision Making. Jakarta: Erlangga.

[42] Saragih, Hidayah Asfaro and Setyaningrum, Dyah. 2015. The Influence of Functional and Legislative Supervision on the performance of Local Government in Indonesia 2011-2012. XVIII National Accounting Symposium in Medan.

[43] Sudarsana, Hafidh and Rahardjo, Shiddiq. 2013. "The Influence of Regional Government
Characteristics and BPK Audit Findings on Regional Government Performance". E-Journal. Diponegoro Journal Of Accounting. Volume2 Number 4. Pp. 1-13.ISSN (online): 2337-3806.

[44] Sugiono. 2013. Combination Research Methods: Mixed Methods. Bandung: Alfabeta.

[45] Sumarjo, Hendro. 2010. The Influence of Regional Government Characteristics on Regional Government Financial Performance. Empirical Study of District / City Government in Indonesia. Undergraduate Thesis. Sebelas Maret University. Surakarta.

[46] Sumawan, I.W., and I.M. Sukarta. Factors Affecting Performance

[47] Regency / City Government Expenditures in Bali Province. E-Journal of Accounting at Udayana University, 14 (3): 1727-1754.

[48] Sesotyaningtyas, Mirna. 2012. "The effect of leverage, legislative size, intergovermental revenue, local tax revenue on the financial performance of regional governments". Accounting analysis journal (Vol.1 no.1). ISSN: 2252-6765.

[49] Suoth, Novelya, Tinangon, Jantjedan, sintje. 2016. "Measurement of the Efficiency and Effectiveness of Regional Financial Management at the Finance, Revenue and Asset Management Office (DPKPA) of South Minahasa Regency". Journal of EMBA, Vol. 4. No.1 March 2016. 613-622.ISSN 23031174 .

[50] Tama, Adi. (2018). "The Effect of Regional Head Characteristics, Government Size and Audit Findings on Regional Financial Performance". Journal. Satya Wacana Christian University: Central Java

[51] Yusrianti, Hasni and Safitri, Rika. 2015. "Implementation of the Government Agency Performance Accountability System (SAKIP) in Regional Work Units (SKPD) within the Government". Journal of Management \& business. 